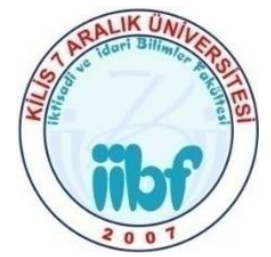

\title{
İndirim Duyarlıı̆ğının İmpulsif Satın Alma Davranışına Etkisinde Mağazaya Ait Uyarıcıların Düzenleyici Rolü
}

\author{
The Regulatory Role of Stimulants Against Store in the Effect of Discount \\ Sensitivity on the Impulse Purchase Behavior
}

Nur ÇAĞLAR ÇETINKAYYA ${ }^{1}$

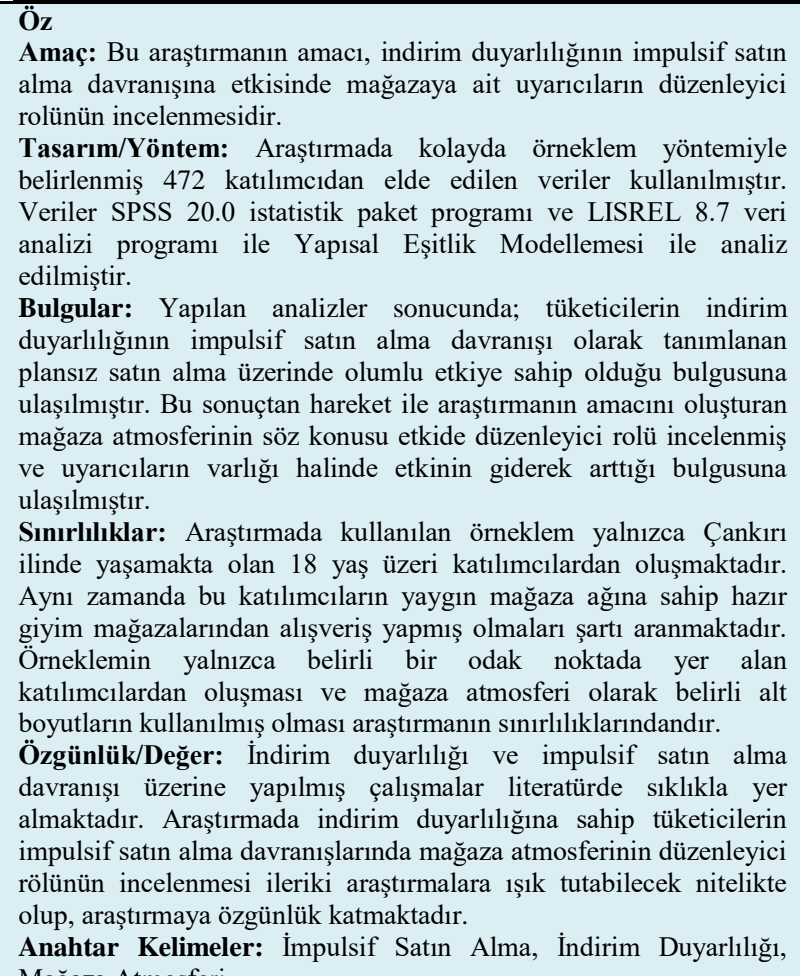

\begin{abstract}
Purpose: This study aims to examine the moderator role of store stimuli in the effect of discount sensitivity on impulsive buying behaviour.

Design/Methodology: Data obtained from 472 participants determined by convenience sampling method were used in the study. The data were analyzed with SPSS 20.0 statistical package program and LISREL 8.7 data analysis program and Structural Equation Modeling.

Findings: As a result of the analyzes made; It has been found that consumers' discount sensitivity has a positive effect on impulsive buying, which is defined as impulsive buying behaviour. Based on this result, the moderator role of the store atmosphere, which is the aim of the research, was examined and it was found that the effect increases gradually in the presence of stimulants.

Limitations: The sample used in the study consists only of participants over the age of 18 living in Çankırı. At the same time, it is required that these participants have made purchases from readymade clothing stores with a widespread store network. The limitations of the research are that the sample consists of only participants at a certain focal point and that certain sub-dimensions are used as the store atmosphere.

Originality/Value: Studies on discount sensitivity and impulsive buying behaviour are frequently found in the literature. Examination of the regulatory role of the store atmosphere in the impulsive buying behaviour of consumers with discount sensitivity in the research can shed light on future research and adds originality to the research.

Keywords: Impulsive Purchasing, Discount Sensitivity, Store Atmosphere
\end{abstract}

1 Dr. Öğr. Üyesi, Çankırı Karatekin Üniversitesi, Meslek Yüksekokulu, Bankacılık Sigortacılık Programı, nurcaglar@karatekin.edu.tr, ORCID: 0000-0002-6047-2718 


\section{GİRIŞ}

1960'lı yıllarda McCarthy tarafından ortaya atılan pazarlama karması işletmelerin savunma araçları olarak ifade edilmektedir (Berry, 1990). Modern pazarlama stratejilerinin pazarlamanın 4P'si üzerine inşa edilmesi gerektiğini savunan McCarthy, değişen koşullara göre ilave unsurların eklenebileceğini ancak bu dört unsurun asla değişmeyeceğini vurgulamıştır. Birbirinden farklı hedef pazarların taleplerine karşılık vermek amacıyla işletmelerin kullandığı kontrol edilebilir pazarlama aletleri demeti olarak tanımlanan (Ivy, 2008) pazarlama karması unsurlarının kullanımı ve önceliği sektörlere göre değişiklik göstermektedir. Pazarlama karması elemanlarından olan fiyat; mal veya hizmete sahip olma veya kullanımı karşılığı tüketiciler tarafından üreticilere ödenen değerler toplamı olarak tanımlanmaktadır (Kurt, 2015).

Bir ürüne ait fiyat seviyesi işletme için başarı düzeyini belirleyen temel faktörlerin başında yer almaktadır. Ürüne uygulanan fiyat ürünün sağladığı değer hakkında tüketicilere mesaj vermektedir. İşletmeler tarafindan uygulanan etkin bir fiyat politikası ile işletmeler potansiyel rakiplerinin pazara girişlerini engelleyebilmektedir. Satışlar üzerinde yoğun ve hızlı etkiye sahip olan fiyat; işletme karlılığının da en önemli belirleyicisi durumundadır.

Tüketicileri satın almaya özendiren ve yüksek rekabetin söz konusu olduğu pazarlarda işletmelerin yoğun olarak kullandıkları indirim stratejisi, tüketicilerin satın alma konusunda hızlı ve düşünmeden hareket etmelerini sağlamaktadır. İhtiyaç duyulmadığı halde tasarruflu alışveriş yapabilme güdüsü ile tüketicileri satın almaya yönlendiren indirim duyarlılığı, fiyat hassasiyetine sahip tüketiciler için önemli bir unsurdur.

Alışveriş niyetinde olmayan tüketicilerin aniden, plansız ve kendiliğinden gelişen satın alma davranışı olarak tanımlanan impulsif satın alma; düşük fiyat, ihtiyaç, kitlesel dağıtım, reklamlar, ürün teşhiri, ürün ömrünün kısa olması ve depolama kolaylığı sağlaması gibi faktörlerin etkisi sonucu gerçekleşmektedir (Kim, 2003; Stern, 1962). Bu faktörlere ek olarak mağaza atmosferinin tüketicileri impulsif satın almaya yönlendirdiğini ifade eden çalışmalar da literatürde yer almaktadır (Kotler, 1973; Cobb \& Hoyer, 1986; Bitner, 1992; Mattila \& Wirtz, 2001; Baker vd., 2002, Prasad \& Aryasri, 2009; Kaş \& Bozbay, 2017). Bu nedenle mağazaların iç-dış tasarımları ve mağaza atmosferine yönelik unsurların tüketicilerin satın alma kararlarında önemli etkiye sahip olduğu görülmektedir.

Son yıllarda tüketicilerin sıkça ihtiyaç haricinde plansız ve anlık karar vererek satın alma faaliyeti gerçekleştirdikleri görülmektedir (Özgüven, 2015). Bu durumun farkında olan işletmeler tüketicileri impulsif satın almaya sevk eden uygulamalara yönelmiştir. Ayrıca tüketicilerin satın alma davranışlarında mağazaya ait uyarıcıların da etkili olduğu bilinmektedir. İşletmeler; aydınlatma, ses düzeni, mağaza personeli ve mağaza ortamı gibi değişkenlerin oluşturduğu mağaza atmosferi ile tüketicilerin satın alma kararlarını etkilemeye çalışmaktadır. Bu araştırmada tüketicilerin indirim duyarlılı̆̆ının impulsif satın almaya etkisinde mağazaya ait uyarıcıların düzenleyici rolünün test edilmesi amaçlanmaktadır. Mağaza atmosferi ve fiyat indirimlerinin satın alma niyetine etkisi konularında literatürde pek çok çalışma yer almakla birlikte indirim duyarlılığın impulsif satın almaya etkisini mağaza atmosferi perspektifinden değerlendiren çalışmaların oldukça sınırlı olduğu görülmektedir. Bu açıdan çalışmanın literatüre önemli bir katkı sağlayacağı beklenmektedir.

\section{KURAMSAL CERÇEVE}

Kavramsal çerçeve kapsamında tüketicilerin indirim duyarlılıkları, impulsif satın alma davranışı ve mağaza atmosferi konuları incelenmiş ve literatür taraması yapılmıştır.

\section{1. İndirim Duyarlılığı}

Tüketiciler tarafından algılanan fiyat satın alma davranışını etkileyen en önemli unsuru oluşturmaktadır. Mal ya da hizmetin normal fiyatın altında oluşan bir fiyattan satın alımına yönelik eğilimi ya da tüketicilerin promosyonlara olan yatkınlığı olarak tanımlanan indirim duyarlılığı; indirimli fiyatlarla tüketicilerin satın alma niyetlerini olumlu yönde etkileyen bir boyutu oluşturmaktadır (Lichtenstein vd., 1993; Jin \& Sternquist, 2003). İndirime duyarlı olan tüketicilerin genellikle düşük fiyatlı ürünleri satın almak için araştırma yaptıkları ve fiyat indirimlerine karşı hassasiyeti artan tüketicilerin satın alma eğilimlerinin yüksek olduğu bilinmektedir. Ürüne uygulanan 
indirimli fiyatın alternatif ürünler ile karşılaştırılarak ürünün değerinin indirimli fiyatın üzerinde olduğunu fark eden tüketiciler satın alma eylemini gerçekleştirmektedirler (Feick \& Price, 1987).

İndirim duyarlılığı ile ilgili literatürde yer alan çalışmalar incelendiğinde; Monroe ve Chapman (1987) tarafından yapılan çalı̧̧mada tüketicilere indirimli ve indirimsiz fiyatın birlikte sunulması halinde tüketicilerin indirimli fiyattan satın alma eylemi gerçekleştirme eğiliminde oldukları gözlemlenmiştir.

Licata ve diğerleri (1998) tarafından yapılan çalışmada ise tüketicilerin demografik özelliklerinden yaşın etkisi incelenmiş, indirimlere yaşlı tüketicilerin genç tüketicilerden daha duyarlı oldukları sonucuna ulaşılmıştır.

Moore ve diğerleri (2003) yaptıkları çalışmada Amerikan ve Polonyalı tüketiciler arasında fiyat algısı karşıllaştırması yapmış, her iki ülkeden tüketicilerin indirim duyarlılığı dışındaki diğer fiyat algısı boyutlarında benzeşen özellikler taşıdıkları sonucuna ulaşılmıştır.

Wathcravesringkan ve diğerleri (2008) tarafindan yapılan çalışmada indirim duyarlılı̆̆ edinim-işlem fayda teorisi ile ilişkilendirilmiş, tüketicilerin söz konusu ürünü indirimli fiyattan satın almalarının hedonik fayda sağlamasından ziyade satın alma ile elde edilen hak olarak kabul edildiği sonucuna ulaşılmıştır.

$\mathrm{Yu}$ (2008) tarafından yapılan bir çalışmada ise online ve offline alışveriş yapan tüketiciler karşılaştırılmış, online alışveriş yapan tüketicilerin offline alışveriş yapan tüketicilere göre fiyat bilinci, indirim duyarlılığ ve değer bilincinin daha fazla olduğu sonucuna ulaşılmıştır.

Khare ve diğerleri (2014), Topuz ve Çambaş1 (2014), Ferreira ve Coelho (2015) tarafindan yapılan çalışmalarda da indirim duyarlılığının tüketicilerin satın alma niyetlerine olan etkisi incelenmiş ve aralarında pozitif yönlü bir ilişkinin bulunduğu sonuçlarına ulaşı1mıştır.

Literatürden elde edilen bulgular 1şığında tüketicilerin indirim duyarlılığının satın alma davranışı üzerinde etkiye sahip olduğu görülmektedir.

\section{2. İmpulsif Satın Alma}

Tüketicilerin satın almak istedikleri mal ve hizmetlere ait pek çok alternatif arasından detaylı değerlendirme yapmaları sonucu gelişen karar alma süreci rasyonellik ilkesine dayanmaktadır. Rasyonellik ilkesine dayanmayan, alternatiflerin detaylıca değerlendirilmediği ve ürün ile ilgili yeterli bilgiye sahip olunmadan yapılan satın almalar ise anlık satın alma ya da impulsif satın alma olarak ifade edilmektedir. Stern'e (1962) göre tüketicilerin önceden planlamadıkları herhangi bir şeyi satın almaları impulsif satın alma davranışı olarak ifade edilmiştir. Rook (1987) ise impulsif satın almayı hızlı bir şekilde ve paylaşımsız olarak tanımlamaktadır. Beatty ve Ferrell (1998) impulsif satın almayı tüketicilerin herhangi bir mal veya hizmete karşı satın alma niyeti bulunmaksızın ortaya çıkan ani ve plansız davranış olarak tanımlanmaktadır.

Stern'e (1962) göre impulsif satın alma davranışının alt boyutlarını; tamamen plansız satın alma, hatırlatmalarla yapılan anlık satın alma, öneri ile yapılan anlık satın alma ve tüketicilerin mağaza içerisinde iken çeşitli uyarıcıların etkisinde kalarak ekonomik fayda sağlayacağı düşüncesiyle satın alması olarak tanımlanan planlı yapılan anlık satın alma oluşturmaktadır.

Literatürde impulsif satın alma davranışını etkileyen faktörler hakkında ortak bir kanı bulunmamaktadır. Ancak satın alma davranışını etkileyen faktörler olan kişisel özellikler, ürüne ait özellikler ve dış uyarıcıların benzer şekilde impulsif satın alma davranışını da etkilediği söylenebilmektedir. Kişisel özellikler arasında yer alan indirim hassasiyeti aynı zamanda ürüne ait özellik olan fiyat ile örtüşerek güçlü bir etmeni oluşturmaktadır. Ayrıca son 10 yılda yapılan bir takım çalışmalarda da artan yoğun internet kullanımına bağlı olarak sosyal medyanın da impulsif satın alma davranışında önemli role sahip olduğu vurgulanmaktadır (Rehman vd., 2014; Triwidisari vd., 2017; Sharma vd., 2018).

İmpulsif satın alma davranışında tüketicilere ait kişisel özellikler ile birlikte mağazaya ait uyarıcıların da etkili olduğu bilinmektedir. Mağaza atmosferini oluşturan koku, renk, ses gibi unsurların etkisi ile tüketicilerin kendilerini keyifli hissetmeleri tüketicilerin mağaza içinde daha uzun 
süre kalmalarını ve impulsif satın almalarını etkilemektedir. Abrat ve Goodey (1990), Piron (1991), Zhou ve Wong (2004), Kaur ve Singh (2007), Mattila ve Wirtz (2008) tarafından yapılan çalışmalar da mağazaya ait unsurların impulsif satın alma davranışını etkilediğini desteklemektedir.

\subsection{Mağazaya Ait Uyarıcılar}

Mağaza atmosferi olarak da ifade edilen mağazaya ait uyarıcılar; müşterilerin algılarını harekete geçirmek, duygularına karşıllı vermek ve sonunda satın alma eylemini gerçekleştirmeye yönelik olan aydınlatma, renklendirme, ses ve koku gibi uyarıcılardan oluşmaktadır (Kaltcheva \& Weitz, 2006). Mağazaya ait uyarıcılar tüketicilerin satın alma kararlarında oldukça etkilidir. Hatta bazı durumlarda ürünün bulunduğu mağazaya ait uyarıcıların tüketicilerin satın alma kararlarında üründen daha etkili olduğu görülmektedir (Kotler, 1973).

Mağazalarda tüketicilerin alışveriş yapma eğilimini artırmak amacıyla müşterilere yönelik duyusal etki uyandıran atmosfer, tüketicileri fiziksel ve psikolojik olarak etkilemektedir. Mağaza atmosferi müşteriler üzerinde yaklaşma ve uzaklaşma şeklinde iki ayrı psikolojik etki uyandırmaktadır. Mağaza atmosferi konusunda işletmelerin amacı müşterilerin mağazada daha fazla zaman geçirmeleri için alışverişin ve alışveriş ortamının keyifli olmasını sağlamaktır. Zira müşterilerin mağazada daha fazla zaman geçirmesini onları impulsif satın alma faaliyetine yönlendirmektedir.

Mağaza çekiciliğini artırmaya ve bu sayede mağaza atmosferi oluşturmaya yönelik literatürde çok sayıda çalışma bulunmaktadır. (Kotler, 1973; Mehrabian \& Russell, 1974; Arslan, 2004; Turley \& Milliman, 2000; Baker vd., 2002; Pantano, 2014). Mağaza ortamında müşterilerin duyu organlarına yönelik uyarıcılar ile oluşturulan mağaza atmosferi tüketici davranışları üzerinde önemli bir etkiye sahiptir (Kim \& Lennon, 2009).

Son yıllarda tüketicilerin ihtiyaç duydukları ürünleri satın almalarından çok, ihtiyaç duymadıkları ürünleri anlık karar vererek satın aldıkları görülmektedir. Bu durumun bilincinde olan işletmeler tarafından tüketicileri impulsif satın almaya yönlendiren unsurlar incelenmiş ve indirim duyarlılı̆̆ının bu unsurlar arasında önemli bir etkiye sahip olduğu sonucuna ulaşılmıştır. Benzer şekilde mağazaya ait uyarıcıların da tüketicileri impulsif satın alma davranışına yönlendirdiği görülmektedir (Parboteeah vd., 2009; Spies vd., 1997).

Mağaza ortamı, tasarımı, düzeni, insan unsuru ve ürün sunumu bileşenlerinden oluşan mağazaya ait uyarıcılar tüketicilerin satın alma davranışları üzerinde önemli bir etkiye sahiptir. $\mathrm{Bu}$ unsurlardan ürün sunumu ve tasarım konusunda Solomon ve diğerleri (2014) tarafindan yapılan bir çalışmada raf sisteminin doğru dizayn edilmesinin tüketicilerin impulsif satın alma kararlarında yaklaşık olarak \%10'luk bir artış yarattığı sonucuna ulaşılmıştır. Ayrıca Corstjens ve diğerleri (1995) tarafından yapılan bir başka çalışmada da ürünlerin müşterilerin göz hizalarında ve raf sonunda bulunmasının tüketicilerin impulsif satın alma kararlarını etkilediği sonucu elde edilmiştir. Bu nedenle tasarımın impulsif satın alma kararlarında etkili olduğu görülmektedir.

İmpulsif satın alma kararlarında etkili olan bir diğer faktör ise mağazanın görünümünü, kokusunu ve ses faktörlerini içeren mağaza ortamıdır. Machleit ve Eroğlu (2000) tarafından yapılan bir çalışmada mağazada tercih edilen müziğin tüketicilerde davranışsal ve duygusal tepkiler uyandırdığı sonucuna ulaşılmıştır. Ayrıca Chebat ve Morin (2005) tarafından yapılan bir çalışmada da mağazada çalan müziğin tüketicileri impulsif satın alma davranışına yönlendirdiği ifade edilmiştir.

Satış görevlilerinden oluşan insan faktörü de impulsif satın alma davranışını etkileyen bir diğer önemli faktördür. Stern (1962) çalışmasında mağazada yer alan ürünler hakkında yeterli bilgiye sahip olan çalışanların müşterileri impulsif satın almaya yönlendirdiklerini ifade etmiştir.

Araştırmada mağazaya ait uyarıcılar tasarım, düzen, ortam, insan unsuru ve ürün sunumu boyutlarıyla incelenmiştir. Mağazada müşterilere dinletilen müziğin türü, sesin şiddeti ve aydınlatma sistemi mağazaya ait ortam boyutu altında incelenmiştir. Mağazada kullanılan renklendirme, mağaza içi dekorasyonun cezbediciliği, reyonlar arası uyumluluk ve reyonlar arası bölümlendirmenin makul olması mağazaya ait tasarımın alt boyutlarını oluşturmaktadır. Reyon düzeni, etkileyici ürünlerin varlığı, yönlendirici tabelaların kullanılmış olması ve mağaza içi dekor ise mağaza düzeninin alt boyutları olarak tanımlanmıştır. Araştırmada incelenen mağazaya ait insan unsuru boyutu ise; istekli çalışanlar, çalışanların kıyafet titizliği, yardım etme istekliliği, bilgi düzeyleri ve çalışan nezaketi alt 
boyutları ile mağazaya ait ürün sunumu boyutu ise ürünlerin güvenilirliği, geniş ürün yelpazesi sunulmas1 ve ürünlerin modaya uygunluğu açısından değerlendirilmiştir.

$\mathrm{Bu}$ araştırma indirim duyarlılığının impulsif satın almaya etkisinde mağazaya ait uyarıcıların düzenleyici etkisini ölçmeyi amaçlamaktadır. Satın alma kararlarında tüketicilere ait bir özellik olan indirim duyarlılı̆ $\breve{g}_{1}$ impulsif satın alma eylemini harekete geçiren bir uyarıcıdır. Bu nedenle indirim duyarlılı̆̆ının impulsif satın alma kararlarında doğrudan etkili olduğu görülmektedir. Ancak müşterilerin satın almak istedikleri mal veya hizmetin sunulduğu mağazaya ait uyarıcıların da impulsif satın alma kararlarında etkili olduğu bilinmektedir. Mağazaya ait uyarıcılar olan ses, aydınlatma, raf düzeni ve insan gibi faktörlerin müşterilerin mağazada geçirecekleri süreyi doğrudan etkilediği düşünüldügünnde müşterilerin bu süre içerisinde planlamadıkları daha fazla ürün satın almaları kaçınılmazdır.

\section{METODOLOJI}

Pazarlamanın odak noktalarından birini oluşturan tüketici davranışı oldukça karmaşık bir yapıya sahiptir. Tüketici davranışlarına kaynak oluşturmak amacıyla tüketicilere ait kişisel özelliklerin dış uyarıcılar ile birleşerek impulsif satın alma davranışına olan etkisini belirlemek araştırmanın odak noktasını oluşturmaktadır. Araştırmada tüketicilerin indirim duyarlılıklarının plansız (impulsif) satın alma davranışlarına etkisinde mağazaya ait uyarıcıların düzenleyici rolünün olup olmadığı araştırılmıştır. Araştırmanın plansız satın alma kararı konusunda tüketicilerin indirim duyarlılıklarını mağaza atmosferi kapsamında değerlendirerek işletmelere yol göstermesi ve farkındalık oluşturabilmesi amaçlanmaktadır. Veri toplama formundan elde edilen veriler SPSS 20.0 istatistik paket programı ve LISREL 8.7 veri analizi programı ile Yapısal Eşitlik Modellemesi ile analiz edilmiştir.

\subsection{Araştırmanın Modeli ve Hipotezlerin Oluşturulması}

Tüketicileri impulsif satın almaya yönelten nedenler ürüne ve tüketiciye yönelik olmak üzere iki grupta toplanmaktadır (Rook, 1987). Araştırmada ürüne yönelik olarak fiyat, tüketiciye yönelik olarak psikolojik etkiye sahip indirim duyarlılığ (Degeratu vd., 2000) ve çevresel etkiye sahip mağaza atmosferi (Kotler, 1973; Spangenberg vd., 2005) incelenmektedir. İndirim duyarlılığı olan tüketicilerin impulsif satın alma davranışı gösterdikleri bilinmektedir (Beatty \& Ferrell, 1998; Mattial \& Wirts, 2008; Pentecost \& Andrews, 2010). İmpulsif satın alma davranışı ise tüketicilerin alışveriş yaptıkları mağazada daha uzun süre kalmalarına bağlıdır (Kumar \& Kim; 2014; Liu vd., 2013, Saad \& Metawie, 2015). Bu nedenle araştırmada indirim duyarlılığına sahip olan tüketicilerin satın alma eylemini gerçekleştirecekleri mağazada daha uzun süre kalmaları mağaza atmosferi ile ilişkilendirilmiştir. $\mathrm{Bu}$ nedenle mağaza atmosferinden etkilenen tüketicilerin daha fazla impulsif satın alma davranışı gösterdikleri görüşünden hareketle araştırma modeli Şekil 1'deki gibi oluşturulmuştur.

Şekil 1: Araştırmanın Modeli

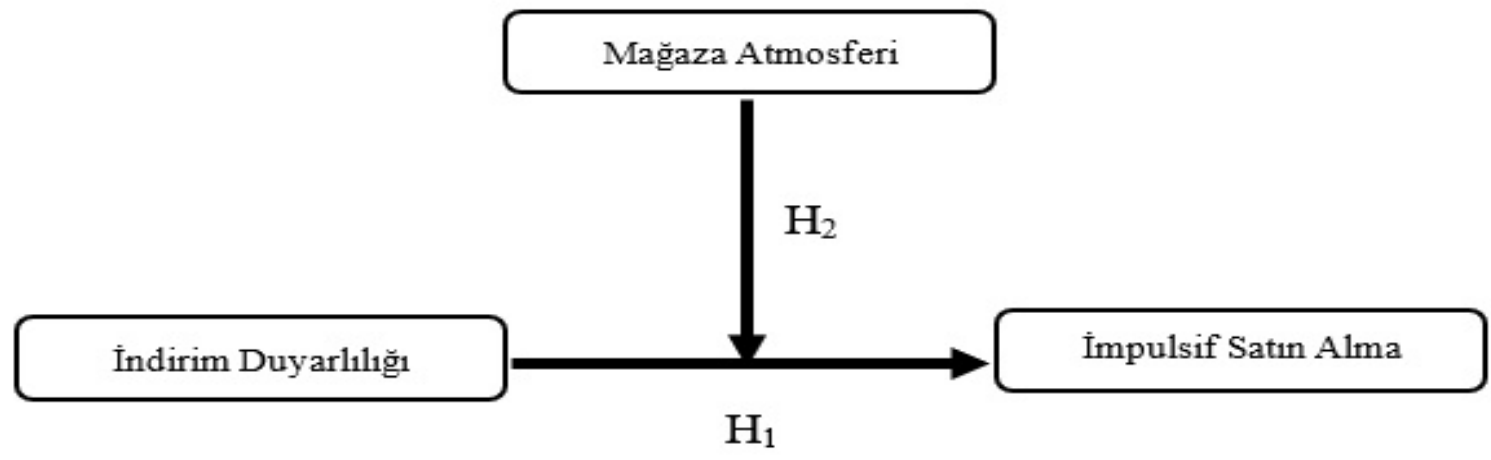

Araştırmanın modelini oluşturan Şekil 1'de indirim duyarlılığının impulsif satın alma davranışını etkilediği görülmektedir. Bu nedenle araştırmada ilk hipotez aşağıdaki gibidir.

$\boldsymbol{H}_{1}$ : İndirim duyarlılı̆̆ı impulsif satın alma davranışını etkilemektedir. 
İndirim duyarlılığından etkilenerek mağazaya gelen müşterilerin mağaza atmosferinin etkisinde kalarak mağaza içerisinde daha uzun zaman geçirmeleri onları daha fazla impulsif satın alma davranışına yönlendirmektedir. Bu nedenle araştırmada ikinci hipotez aşağıdaki gibidir.

$\boldsymbol{H}_{2}$ : İndirim duyarlılı̆̆ının impulsif satın alma davranışına etkisinde mă̆azaya ait uyarıcıların düzenleyici rolü vardır.

\subsection{Araștırmanın Evreni, Örneklemi ve Örnekleme Yöntemi}

Araştırmanın evrenini son bir sene içerisinde ülke genelinde yaygın mağaza ağına sahip olan hazır giyim mağazalarından alışveriş yapmış 18 yaş üzeri katılımcılar oluşturmaktadır. Hazır giyim sektörü özellikle son yıllarda hızla gelişme göstermiş ve Türkiye'de geniş pazar payına sahip olan sektörlerden biridir. Oldukça geniş tüketici kitlesine hitap eden bu sektörde farklı ölçeklere sahip pek çok işletme yer almaktadır. İnsanlar için son derece önemli olan giyim; insanların pek çok özelliği hakkında karşısındakilere mesaj verir niteliktedir. Tüketicilerin yenilenme arzusu, modaya uygunluk, rahatlık ve ihtiyaç gibi pek çok nedenden dolayı hazır giyim ürünleri tükettikleri görülmektedir. Başta genç tüketicilerin hazır giyim ürünleri satın alma kararları üzerinde yoğunlaşmaları araştırmanın bu sektörde yapılmasını gerekli kılmıştır.

Anket formu Çankırı ilinde uygulanmış ve katılımcılar kolayda örnekleme yöntemi ile seçilmiştir. Ankette yer alan ifadelerin anlaşılırlığının ve ölçeklerin güvenirliğinin sınanması amacıyla 50 katılımcıya ön test uygulanmış, elde edilen anket sonuçları ve katılımcıların geri bildirimlerine göre bazı anket soruları yeniden düzenlenmiştir. Anket 01/03/2021 ve 15/04/2021 tarihleri arasında uygulanmış olup, 472 katılımcıdan elde edilen cevaplar incelenmiş, 465 kullanılabilir anket araştırmaya dahil edilerek değerlendirilmiştir. Çankırı Karatekin Üniversitesi Etik Kurulu'nun 01/03/2021 tarih ve 419 sayılı kararı ile çalışmanın etik ilkelere uygun olduğu kararı sonrasında araştırma gerçekleştirilmiştir.

\subsection{Araştırmanın Veri Toplama Araçları}

Araştırmada literatür taraması sonucu daha önce yapılan çalışmalar doğrultusunda orijinal ölçeklerden uyarlanmış iki kısımdan oluşan bir veri toplama formu uygulanmıştır. Birinci kısımda demografik özellikleri belirlemek adına katılımcılara yöneltilmiş 6 soru yer almaktadır. Çalışmanın ikinci kısmında ise tüketicilerin indirim duyarlılığını, impulsif satın alma kararlarını ve mağazaya ait uyarıcıları ölçmek amacıyla çeşitli sorular yöneltilmiştir. Tüketicilerin indirim duyarlılığını (INDDUY) ölçmek amaciyla Lichtenstein ve diğerlerinin (1995), Mishra ve Shukla'nın (2013) çalışmalarında kullandıkları ölçeklerden uyarlanmış 6 soru, tüketicilerin impulsif satın alma kararlarını (IMPSTN) ölçmek amaciyla Rook ve Fisher (1995), Park ve diğerlerinin (2006) çalıșmalarında kullandıkları orijinal ölçeklerden uyarlanmış 9 soru ve mağazaya ait uyarıcıların etkilerini ölçmek amaciyla Baker ve diğerleri (1994), Wakefield ve Baker (1998), Kumar ve Kim (2014) tarafindan yapılan çalışmalarda kullanılan orijinal ölçeklerden uyarlanmış 24 soru yöneltilmiş ve katılımcıların 5'li Likert ölçeği ile yanıtlamaları istenilmiştir. Mağazaya ait uyarıcıları ölçmek üzere katılımcılara yöneltilen 24 soru; mağazaya ait ortamı ölçmek üzere 5 soru (MAO), mağazaya ait tasarımı ölçmek üzere 5 soru (MAT), mağazaya ait düzeni ölçmek üzere 4 soru (MAD), mağaza çalışanlarının etkisini ölçmek üzere 6 soru (MAI) ve mağazada ürün sunumunu ölçmek üzere 4 soru (MAUS) şeklinde dağılım göstermektedir.

Mağazaya ait uyarıcıları oluşturan alt boyutların mağaza atmosferine olan etkileri de araştırmada ayrıca analiz edilecektir. Alt boyutlar ile mağaza atmosferi arasında anlamlı bir ilişkinin bulunması halinde alt boyutların oluşturduğu mağaza atmosferi araştırmada tek bir değişken olarak incelenecektir. Araștırmada amaç; indirim duyarlılığının impulsif satın alma niyetine etkisinde mağaza atmosferini oluşturan unsurları bir bütün olarak ele alıp aracılık etkisini ölçümlemektir. Ancak ileriki çalışmalarda mağazaya ait söz konusu uyarıcıların faktör bazında incelenmesi mümkündür.

\section{ANALIZ VE BULGULAR}

Araştırmaya katılan katılımcılardan elde edilen demografik özellikler incelendiğinde elde edilen veriler Tablo 1'de yer almaktadır. Katılımcıların büyük çoğunluğunu kadın tüketiciler $(\% 69,9)$ oluşturmaktadır. Katılımcıların \%64,5'i bekar ve \%57'sinin yaş aralığının 18-23 olduğu belirlenmiştir. 
Ayrıca araştırmaya katılan tüketicilerin \%55,9'unun önlisans eğitimi aldıkları ve \%39,8'inin gelir durumunun 0-2500 TL arasında olduğu tespit edilmiştir.

Tablo 1: Demografik Özellikler

\begin{tabular}{|c|c|c|c|c|c|}
\hline & Frekans (N) & Yüzde (\%) & & Frekans $(\mathbf{N})$ & Yüzde (\%) \\
\hline Cinsiyet & & & Medeni Durum & & \\
\hline Kadın & 325 & 69,9 & Evli & 165 & 35,5 \\
\hline Erkek & 140 & 30,1 & Bekar & 300 & 64,5 \\
\hline Yaş & & & Meslek & & \\
\hline $18-23$ & 265 & 57 & Kamu Çalışanı & 75 & 16,1 \\
\hline $24-29$ & 75 & 16,1 & Serbest Meslek Sahibi & 15 & 3,2 \\
\hline $30-35$ & 25 & 5,4 & Özel Sektör Çalışanı & 15 & 3,2 \\
\hline $36-41$ & 65 & 14 & Ev Hanımı/İşsiz & 50 & 10,9 \\
\hline $42-47$ & 15 & 3,2 & Öğrenci & 75 & 16,1 \\
\hline 48 ve üzeri & 20 & 4,3 & Emekli & 235 & 50,5 \\
\hline Aylık Gelir & & & Öğrenim Durumu & & \\
\hline $0-2500 \mathrm{TL}$ & 185 & 39,8 & İlköğretim & 5 & 1,1 \\
\hline $2501-5000 \mathrm{TL}$ & 165 & 35,4 & Lise & 40 & 8,6 \\
\hline $5001-7500 \mathrm{TL}$ & 65 & 14 & Önlisans & 260 & 55,9 \\
\hline $7501-10.000 \mathrm{TL}$ & 20 & 4,3 & Lisans & 105 & 22,6 \\
\hline $10.001 \mathrm{TL}$ ve üzeri & 30 & 6,5 & Lisansüstü & 55 & 11,8 \\
\hline
\end{tabular}

Anket formunda farklı çalışmalardan uyarlanmış ölçekler kullanılmıştır. Orijinal ölçeklerin yabancı dilde olması nedeniyle öncelikle ölçekler Türkçe'ye çevrilmiş, ardından açıklayıcı faktör analizi yapılmıștır. Kaise-Meyer-Olkin (KMO) değerinin 0,60'tan büyük olması ve Bartlett Küresellik Testi sonucunun $\mathrm{p}<0,05$ olması faktör analizinin yapılabilmesinin ön koşuludur. Araştırmada elde edilen $\mathrm{KMO}$ değeri 0,60 'nn üzerindedir $(\mathrm{KMO}=0,864)$. Bartlett Küresellik Testi sonucuna göre de değişkenler arasında yeterli ilişki bulunmuştur $(\mathrm{p}<0,05, \mathrm{p}=0,000)$. Araştırmada değişkenlerin çarpıklık ve basıklık değerleri de incelenmiş, Hair vd. (1998) tarafından belirlenen \pm 2 aralığında değerler aldıkları görülmüştür.

Tablo 2: Faktör Analizi Sonuçları

\begin{tabular}{|c|c|c|c|c|}
\hline Faktörler & Madde No & Faktör Ăgırlıkları & Faktör Açıklayıcıları & Cronbach Alpha \\
\hline \multirow{24}{*}{ 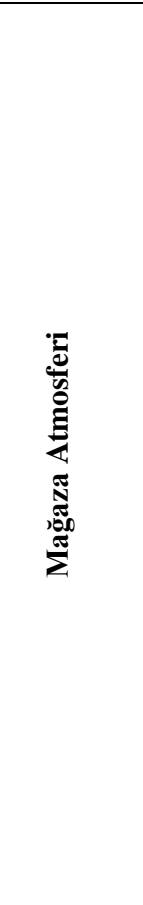 } & MAT 4 & 0,970 & \multirow{24}{*}{47,823} & \multirow{24}{*}{ (1) } \\
\hline & MAD3 & 0,961 & & \\
\hline & MAI5 & 0,946 & & \\
\hline & MAD1 & 0,934 & & \\
\hline & MAI1 & 0,913 & & \\
\hline & MAD4 & 0,912 & & \\
\hline & MAD2 & 0,898 & & \\
\hline & MAUS1 & 0,897 & & \\
\hline & MAI3 & 0,894 & & \\
\hline & MAI2 & 0,892 & & \\
\hline & MAO4 & 0,888 & & \\
\hline & MAI6 & 0,872 & & \\
\hline & MAUS3 & 0,859 & & \\
\hline & MAO5 & 0,845 & & \\
\hline & MAT3 & 0,842 & & \\
\hline & MAUS2 & 0,830 & & \\
\hline & $\mathrm{MAO} 2$ & 0,823 & & \\
\hline & MAT1 & 0,798 & & \\
\hline & MAUS4 & 0,741 & & \\
\hline & MAT5 & 0,721 & & \\
\hline & MAO3 & 0,679 & & \\
\hline & MAI4 & 0,647 & & \\
\hline & MAO1 & 0,621 & & \\
\hline & MAT2 & 0,611 & & \\
\hline
\end{tabular}


Tablo 2 (Devamı): Faktör Analizi Sonuçları

\begin{tabular}{|c|c|c|c|c|}
\hline Faktörler & Madde No & Faktör Ağırlıkları & Faktör Açıklayıcıları & Cronbach Alpha \\
\hline \multirow{9}{*}{ 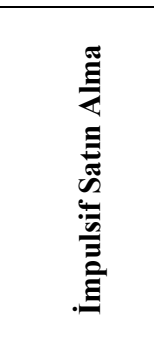 } & IMPSTN3 & 0,935 & \multirow{9}{*}{23,393} & \multirow{9}{*}{0,796} \\
\hline & IMPSTN1 & 0,934 & & \\
\hline & IMPSTN2 & 0,879 & & \\
\hline & IMPSTN4 & 0,870 & & \\
\hline & IMPSTN5 & 0,851 & & \\
\hline & IMPSTN8 & 0,827 & & \\
\hline & IMPSTN9 & 0,826 & & \\
\hline & IMPSTN7 & 0,732 & & \\
\hline & IMPSTN6 & 0,716 & & \\
\hline \multirow{6}{*}{ 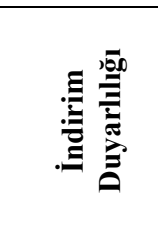 } & INDDUY3 & 0,834 & \multirow{6}{*}{7,595} & \multirow{6}{*}{0,787} \\
\hline & INDDUY1 & 0,790 & & \\
\hline & INDDUY2 & 0,783 & & \\
\hline & INDDUY4 & 0,777 & & \\
\hline & INDDUY5 & 0,754 & & \\
\hline & INDDUY6 & 0,714 & & \\
\hline Toplam & & & 78,811 & 0,906 \\
\hline
\end{tabular}

Kaiser-Meyer-Olkin Ölçek Geçerliliği= 0,864 $\quad$ Bartlett Küresellik Testi Ki Kare $(741)=14385,838 ; p=0,000$

Araştırmada mağazaya ait uyarıcıları oluşturan alt boyutların (MAT, MAD, MAO, MAI, MAUS) tek boyut altında toplanması amaçlanmıştır. Bu durum faktör analizinin aynı yapıyı ölçümlemek üzere bir araya getirilmiş değişkenleri ölçmek amacıyla en sayıda faktör ile ölçümlemeyi amaçlayan istatistiksel bir analiz olduğu (Kurtuluş, 2006) görüşü ile desteklenmektedir. İndirim duyarlılı̆̆ının impulsif satın almaya etkisinde mağazaya ait uyarıcıların aracılık etkisi olup olmadığını ölçümlemeyi amaçlayan araştırmada mağaza atmosferinin tek boyut altında incelenmesi değişkenleri arası ilişkinin çift yönlü incelenmesini de kolaylaştıracaktır.

Faktör analizi sonucu elde edilen bulgulara göre araştırmada incelenen değişkenlere ait alt boyutları oluşturan soru gruplarının araştırmaya uygun olacak şekilde faktör dağılımı gösterdiği gözlemlenmektedir. Tablo 2'de araştırmada kullanılan 39 maddelik ölçeğin beklenilen düzeyde 3 boyut altında toplandığı ve bu faktörlerin toplam varyansın \%78,811'ini açıkladığı bulgusuna ulaşılmıştır. Ayrıca faktörlerin içsel tutarlılıklarının hesaplanmasında güvenirlik katsayıları incelenmiş, Cronbach Alpha değerlerinin 0,70'in üzerinde olması nedeniyle yüksek güvenirlikte olduğu tespit edilmiştir.

Araştırmada faktör analizi sonrasında LISREL 8.7 programı ile Doğrulayıcı Faktör Analizi gerçekleştirilmiştir. Ankette yer alan 39 soruluk gözlenen değişken ve 3 örtük değişken ile yapılan DFA'da düşük standardize değerine ve yüksek hata düzeyine sahip herhangi bir değişkene rastlanmamıştır.

Tablo 3: DFA Modeli İçin Uyum Kriterlerine Ait Değerler

\begin{tabular}{cccc}
\hline Uyum Kriterleri & Mükemmel Uyum & Kabul Edilebilir Uyum & Ölçeğe Ait Değerler \\
\hline$\chi 2 /$ sd & $\leq 3$ & $\leq 5$ & 4,19 \\
\hline RMSEA & $0<\mathrm{RMSEA}<0,05$ & $0,05 \leq \mathrm{RMSEA} \leq 0,10$ & 0,107 \\
\hline SRMR & $0 \leq \mathrm{SRMR}<0,05$ & $0,05 \leq \mathrm{SRMR} \leq 0,10$ & 0,09 \\
\hline NFI & $0,95 \leq \mathrm{NFI} \leq 1$ & $0,90 \leq \mathrm{NFI}<0,95$ & 0,94 \\
\hline CFI & $0,95 \leq \mathrm{CFI} \leq 1$ & $0,90 \leq \mathrm{CFI}<0,95$ & 0,95 \\
\hline GFI & $0,95 \leq \mathrm{GFI} \leq 1$ & $0,90 \leq \mathrm{GFI}<0,95$ & 0,96 \\
\hline AGFI & $0,90 \leq \mathrm{AGFI} \leq 1$ & $0,85 \leq \mathrm{GFI}<0,90$ & 0,92 \\
\hline
\end{tabular}

Kaynak: Schermelleh-Engel vd., 2003

Tablo 3'te doğrulayıcı faktör analizine ilişkin uyum kriterlerine ait değerler yer almaktadır. Elde edilen uyum iyiliği değerleri incelendiğinde uyum iyiliği değerlerinden $\mathrm{x}^{2} / \mathrm{sd}$, SRMRve NFI'nin kabul edilebilir uyum değerleri aralığında, GFI, AGFI ve CFI değerlerinin ise mükemmel uyum değerleri aralığında yer aldığı görülmektedir. RMSEA değerinin ise kabul edilebilir uyum aralığında olmadığı görülmektedir. Ancak Kim (2009) tarafindan yapılan bir çalışma örneklem büyüklügünün uyum indeksleri üzerinde etkili olduğunu belirtmektedir. Yapısal eşitlik modellemesi analizlerinde makul örneklem büyüklüğü (Hoogland \& Boomsma, 1998; Boomsma \& Hoogland, 2001) 150 ve 200 
olması gerekmektedir. Araştırmada kullanılan örneklem büyüklüğü dikkate alındığında söz konusu değerin aralıkların biraz üzerinde çıkması kabul edilebilir niteliktedir. Ayrıca faktörlere ait Ortalama Açıklanan Varyans (AVE) ve Yapı Güvenilirliği (CR) değerleri de incelenmiş, Mağaza Atmosferi boyutu için $\mathrm{AVE}=0,705 \mathrm{CR}=0,982$, İndirim Duyarlılı̆ 1 boyutu için $\mathrm{AVE}=0,602 \mathrm{CR}=0,900$ ve İmpulsif Satın Alma boyutu için $\mathrm{AVE}=0,713$ ve $\mathrm{CR}=0,957$ sonuçlarına ulaşılmıştır. Elde edilen bu sonuçlardan hareketle araştırmada kurulan modele ait standartlaştırılmış parametre tahminleri, $\mathrm{t}$ değerleri ve hipotezlere ait sonuçlar incelenmiştir.

Tablo 4: Yapısal Eşitlik Modeli Sonucu Elde Edilen Hipotez Testleri Sonuçları

\begin{tabular}{ccccc}
\hline Hipotezler & Yollar & $\begin{array}{c}\text { Standartlaştırılmış Parametre } \\
\text { Tahminleri }\end{array}$ & t değerleri & Sonuç \\
\hline $\mathrm{H}_{1}$ & $\begin{array}{c}\text { Indirim Duyarlılı̆̆ } \rightarrow \text { İmpulsif } \\
\text { Satın Alma Davranış1 }\end{array}$ & 0,27 & 3,17 & Kabul \\
\hline $\mathrm{H}_{1^{*}}$ & $\begin{array}{c}\text { Mağaza Atmosferi } \rightarrow \text { İmpulsif } \\
\text { Satın Alma } \\
\text { Davranış1 }\end{array}$ & 0,19 & 2,39 & Kabul \\
\hline
\end{tabular}

Tablo 4'te elde edilen bulgular sonucunda hipotezlere ait anlamlılık değerleri incelendiğinde indirim duyarlılığı ile impulsif satın alma davranışı arasında $p<0,05$ düzeyinde anlamlı bir ilişki bulunduğu görülmektedir. Benzer şekilde araştırma hipotezleri arasında yalnızca düzenleyici etkisinin incelendiği mağaza atmosferi ve impulsif satın alma davranışı arasındaki ilişki de incelenmiş ve $\mathrm{p}<0,05$ düzeyinde anlamlı bir ilişkinin olduğu sonucuna ulaşılmıştır.

Araştırmanın ikinci hipotezi olan tüketicilerin indirim duyarlılı̆̆ının impulsif satın alma davranışına etkisinde mağazaya ait uyarıcıların düzenleyici etkisi SPSS paket programı üzerinden Process Makro ile analiz edilmiştir. Tahmin ve sonuç değişkenleri arasındaki ilişkinin yönünü ve şiddetini etkileyen değişken olan düzenleyici değişken olarak ifade edilen etkileşim değişkeninin istatistiksel olarak anlamlı olması tahmin değişkeninin sonuç değişkeni üzerindeki etkisini değiştirmektedir.

Tüketici indirim duyarlılığının impulsif satın alma davranışına etkisinde mağazaya ait uyarıcıların düzenleyici etkisini incelemek amacıyla Bootstrap yöntemini temel alan regresyon analizi gerçekleştirilmiştir. Güvenilir sonuçların elde edildiği Bootstrap yöntemi Hayes (2018) tarafindan geliştirilen Process Makro analizi ile uygulanmıştır. İlgili yöntemin kullanıldığı aracılık ve düzenleyicilik etkisi analizlerinde araştırma hipotezlerinin desteklenebilmesi için analiz sonucunda elde edilen \%95 güven aralığındaki değerlerin sıfır değerlerini kapsamaması gerekmektedir.

Tablo 5'ten elde edilen sonuçlara göre regresyon analizi uygulanan tüm tahmin değişkenlerinin impulsif satın alma davranışı üzerindeki değişimin yaklaşık \%20 $\left(\mathrm{R}^{2}=, 200\right)$ açıkladığı görülmüştür. Analiz sonuçlarına göre indirim duyarlılığının impulsif satın alma davranışını olumlu yönde etkilediği görülmektedir $(b=, 5864, p<0,05)$. Mağazaya ait uyarıcılar olarak araştırmada incelenen mağaza atmosferi ve indirim duyarlılığı değişkenlerinin ise impulsif satın alma davranışı üzerindeki etkileşimsel etkisinin (düzenleyici etki) anlamlı olduğu $(b=, 2086, p<0,01)$ saptanmıştır. Yani indirim duyarlılı̆̆ının impulsif satın alma davranışı üzerindeki etkide mağazaya ait uyarıcıların düzenleyici rolü olduğu bulgusuna ulaşılmıştır.

Tablo 5: Düzenleyici Etkiyi Gösteren Regresyon Analizi Sonuçları

\begin{tabular}{|c|c|c|c|}
\hline Değișkenler & b & S.H. & $\mathbf{t}$ \\
\hline Sabit & $\begin{array}{c}2,9622 * * \\
{[1.319,4.605]}\end{array}$ & .836 & 3,543 \\
\hline İndirim Duyarlılı̆̆g & $\begin{array}{c}.5864^{*} \\
{[.0599,1.113]}\end{array}$ & .268 & 2.189 \\
\hline Mağaza Atmosferi & $\begin{array}{c}-0.2746 \\
{[-.6742, .1250]}\end{array}$ & .2033 & -1.350 \\
\hline $\begin{array}{c}\text { İndirim Duyarlılığı x } \\
\text { Mağaza Atmosferi }\end{array}$ & $\begin{array}{c}.2086^{* *} \\
{[.0818, .3354]}\end{array}$ & .0645 & 3.233 \\
\hline
\end{tabular}

Not: $\mathrm{R}=0,45, \mathrm{R}^{2}=0,20 ; * * \mathrm{p}<0,001$, ${ }^{*} \mathrm{p}<0,05 ;$ S.H.: Standart Hata, Parantez içindeki değerler güven aralıklarını göstermektedir. Standardize edilmemiş beta katsayıları (b) raporlanmıştır. 
Tablo 6'da düzenleyici etkiyi gösteren regresyon analizi sonucunda elde edilen standart hata ve $t$ değerleri yer almaktadır. Analizde düzenleyici etki ayrıntılı olarak incelendiğinde mağazaya ait az uyarıcının olduğu durumda indirim duyarlılığının impulsif satın alma davranışına olan etkisinin düşük $(3,4167 \rightarrow .1263)$, orta olduğu durumda orta $(3,9583 \rightarrow .2392)$ ve yüksek olduğu durumda ise etkinin yüksek $(4,5417 \rightarrow .3609)$ olduğu gözlenmiştir. Mağazaya ait uyarıcıların fazla olduğu durumda bu ilişkinin giderek daha da kuvvetlendiği görülmektedir. Aynı zamanda uyarıcıların daha az olduğu durumda da ilişki giderek zayıflamaktadır. Bu bulgular neticesinde $\mathrm{H} 2$ hipotezi desteklenmektedir. Sonuç olarak mağazaya ait fazla ve etkin uyarıcıların olması durumunda tüketicilerin indirim duyarlılığının impulsif satın alma davranışına olan etkisi daha fazla olmaktadır ve söz konusu durum tüketicilerin indirim duyarlılığı ve impulsif satın alma davranışı arasındaki ilişkinin mağazaya ait uyarıcılar tarafından düzenlenip desteklendiği anlamına gelmektedir.

Tablo 6: Düzenleyici Etkiyi Gösteren Regresyon Analizi Sonuçları

\begin{tabular}{cccc}
\hline Değişkenler & b & S.H. & t \\
\hline Düşük (3.467) & $\begin{array}{c}.1263^{*} \\
{[.0088, .2437]}\end{array}$ & .0598 & 2.112 \\
\hline Orta (3.9583) & $\begin{array}{c}.2392^{* *} \\
{[.1586, .3199]}\end{array}$ & .0410 & 5.829 \\
\hline Yüksek (4.5417) & $\begin{array}{c}.3609^{* *} \\
{[.2650, .4569]}\end{array}$ & .0488 & 7.397 \\
\hline
\end{tabular}

Not: $* * \mathrm{p}<0,001,{ }^{*} \mathrm{p}<0,05$; S.H.: Standart Hata, Parantez içindeki değerler güven aralıklarını göstermektedir. Standardize edilmemiş beta katsayıları (b) raporlanmıştır.

\section{SONUÇ}

Tüketicilerin satın alma kararlarında etkin ve önemli bir role sahip olan fiyat aynı zamanda tüketiciler üzerinde psikolojik bir etkiye de sahiptir. Ürün fiyatını rakip markalar ile karşılaştırdığında ürün değerinin indirimli satış fiyatının üzerinde olduğuna karar veren tüketiciler satın alma kararı vermektedir. Fiyat indirimlerinin yer aldığ 1 broşürleri ve indirim etiketlerini dikkate alarak alışveriş̧ yapmak isteyen tüketicilerin normal fiyatı referans alarak değerlendirme yaptıkları ve fiyat hassasiyetine sahip oldukları görülmektedir. Rekabetin yüksek olduğu pazarlarda işletmelerin yoğun olarak uyguladıkları indirim stratejisi tüketicilerin satın alma eylemini hızlı ve düşünmeden gerçekleştirmelerini sağlamaktadır. Tüketiciler tarafından ihtiyaç duyulmadığı halde tasarruflu alışveriş yapabilme güdüsü ile tüketicileri satın almaya yönlendiren indirim duyarlılı̆̆ fiyat hassasiyetine sahip tüketiciler için önemli bir unsurdur.

Tüketiciler tarafindan rasyonellik ilkesine dayanmayan, alternatifler arasında değerlendirme yapmaksızın anlık ve plansız gerçekleșen satın alma eylemi olarak tanımlanan impulsif satın alma; düşük fiyat başta olmak üzere ihtiyaç, reklam, ürün teşhiri ve ürün ömrünün kısa olması gibi pek çok faktörün etkisi altında gerçekleşmektedir. Mağazaya ait uyarıcıların da tüketicilerin impulsif satın alma kararlarını etkilediğini ve mağazada daha fazla zaman geçirmenin tüketicileri impulsif satın alma eylemini gerçekleştirmeye yönlendirdiğini gösteren çalışmalara literatürde rastlanmaktadır (Abrat, 1990; Piron, 1991; Zhou \& Wong, 2003; Kaur \& Singh, 2007; Mattila \& Wirtz, 2008).

Mağaza atmosferi olarak da ifade edilen mağazaya ait uyarıcılar; mağaza tasarımı, mağaza ortamı, mağaza düzeni, mağazada ürün sunumu ve mağazaya ait insan unsuru alt boyutlarından oluşmaktadır. Mağazada müşterilere dinletilen müzik, ses yoğunlu, müziğin türü ve mağaza içi aydınlatma mağazaya ait ortamı, mağazada kullanılan renklendirme, cezbedicilik, ürünlerin uyum içerisinde sergilenmesi ve reyonlar arası bölümlendirmenin makul olması mağazaya ait tasarımı, reyon düzeni, etkileyici ürünlerin sunulması, yönlendirici tabelaların varlığı ve dekor mağazaya ait düzeni, istekli çalışanlar, çalışanların kıyafet düzeni, çalışanların yardım etme istekliliği, bilgi düzeylerinin yeterliliği ve nezaketi mağazaya ait insan unsurunu ve ürünlerin güvenilirliği, geniş ürün yelpazesi ve ürünlerin modaya uygunluğu da mağazaya ait ürün sunumunu oluşturmaktadır ve araştırmada mağazaya ait uyarıcılar bu boyutlar altında incelenmiştir.

Araştırmada yaygın mağaza ağına sahip hazır giyim sektörü incelenmiştir. Hazır giyim sektörü özellikle son yirmi yılda hızla gelişme göstermiş ve Türkiye'de en geniş pazar payına sahip olan sektörlerden biridir. Oldukça geniş bir kesime hitap eden bu sektörde büyük ve küçük ölçekli pek çok işletme yer almaktadır. İnsanlar için son derece önemli olan giyim; insanların ekonomik düzeyleri, 
dünya görüşleri, yaşam tarzları ve benzeri pek çok konu hakkında mesajlar vermektedir. Giyim ürünleri satın alma ihtiyacı kişilerin yenilenme ihtiyacı olabileceği gibi güzel ve şı görünme arzusu, modaya olan yakın ilgi ve ihtiyaçları giderme arzusundan da kaynaklanmaktadır. Özellikle gençlerin hazır giyim ürünleri satın alma kararları üzerinde yoğunlaşmaları araştırmanın bu sektörde yapılmasını gerekli kılmıştır.

Araştırmada hazır giyim ürünleri satın alma eylemi gerçekleştiren katılımcıların indirim duyarlılıkları ve impulsif satın alma davranışına olan etkisi öncelikle incelenmiştir. Yapılan analizler neticesinde indirim duyarlılığı olan fiyat hassasiyetine sahip tüketicilerin impulsif satın alma davranış1 gösterdikleri gözlemlenmiştir. Araştırmadan elde edilen bu sonuç Monroe ve Chapman (1987), Licata ve diğerleri (1998), Khare ve diğerleri (2014), Topuz ve Çambaşı (2014), Ferreira ve Coelho'nun (2015) çalışmalarını destekler niteliktedir. Ancak Licata ve diğerleri (1998) tarafından yapılan çalışmada yaşlı tüketicilerin indirim duyarlılığına genç tüketicilerden daha fazla sahip oldukları görüşü hakimken çalışmada yoğun olarak yer alan 18-23 yaş arası genç tüketicilerin de indirim duyarlılığına sahip oldukları gözlemlenmiştir. Bu durum artan tüketici bilinci ile açıklanmaktadır. İçinde bulundukları kuşağın özelliklerini taşıyan bu tüketicileri araştıran, inceleyen tüketiciler olmaları nedeniyle bilinçli tüketim eğiliminde oldukları tespit edilmiştir. Literatürde hedonizm ile bağdaştırılan impulsif satın alma davranışının tüketicilerin hedonik arzularını tatmin ettiği ve faydacılık ile de örtüştüğü belirtilmektedir (Rook 1987; Piron, 1991; Hausman, 2000). Tüketicilerin impulsif satın alma davranışlarını etkileyen başlıca unsurlar hakkında literatürde ortak bir kanı bulunmamaktadır. Ancak bireysel özellikler, dış uyarıcılar ve ürün ile ilgili faktörlerin tüketicilerin satın alma kararlarında etkili olduğu düşünüldüğünde bu faktörlerin benzer şekilde impulsif satın alma davranışı için de kullanılması mümkün görünmektedir. Bireyleri karakterize eden bireysel özelliklerden olan indirim duyarlılı̆̆ da impulsif satın alma davranışını etkileyen bir faktör olarak belirtilmiş ve analizler ile bulgulanmıştır. Bu durum Stern (1962) tarafından yapılan çalışmadan elde edilen sonuç ile örtüşmekte ve ürünün düşük fiyatlı olmasının plansız satın almayı doğrudan etkilediği görüşü ile desteklenmektedir.

Araştırmada incelenen bir diğer konu ise mağazaya ait uyarıcıların indirim duyarlılığının impulsif satın almaya etkisinde düzenleyici role sahip olup olmadığıdır. Yapılan analizler neticesinde mağazaya ait tasarım, ortam, düzen, insan unsuru ve ürün sunumundan oluşan mağaza atmosferi olarak da tanımlanan mağazaya ait uyarıcıların söz konusu ilişkide düzenleyici role sahip olduğu tespit edilmiştir. $\mathrm{Bu}$ durum indirim duyarlılı̆̆ına sahip tüketicilerin plansız satın alma eylemlerinde mağazaya ait uyarıcıların da etkisinde kaldıkları ve satın alma kararlarının şiddetlerinin değiştiğini ifade etmektedir. İndirim duyarlılığına sahip olsa dahi tüketicilerin mağazada maruz kaldıkları yüksek ses, fazla aydınlatma, yönlendirici tabela yokluğu, çalışan ilgisizliği ve nezaketsizliği gibi etmenler karşısında impulsif satın alma kararlarının şiddetinin azaldığı, aksi durumda ise daha da arttığı sonuçlarına ulaşılmıştır.

Araştırmada incelenen hazır giyim alanında yaygın mağaza ağına sahip işletmelerin tüketicilerin her ne kadar indirim duyarlılığına sahip olsalar dahi mağazaya ait uyarıcıların etkisi altında kalarak satın alma davranışlarının şiddetlerinin değiştiği bulgusu çerçevesinde stratjiler geliştirmeleri önerilmektedir. Zira fiyat hassasiyeti tüketicileri plansız satın almaya yönlendirirken dış uyarıcıların da bu yönelmeyi destekler şekilde düzenlenmesi işletmelerin başarısını artıracaktır. Araştırma yalnızca hazır giyim sektöründe faaliyet gösteren mağazalar açısından incelenmiştir. Farklı alanlarda faaliyet gösteren işletmeler için de yol gösterici nitelikte olması arzulanmaktadır. Aynı zamanda araştırmaya kişilik özellikleri ve markaya güven gibi unsurların eklenmesi ile zenginleştirilebilir ve farklı bir örneklem grubu üzerinde sınanarak yorumlanabilir. Araştırmanın bu özellikleri ile ileriki çalışmalara 1şık tutması beklenmektedir.

Etik Beyan: Bu çalışmada kullanılan anket yöntemi için Çankırı Karatekin Üniversitesi Etik Kurulu'ndan 01/03/2021 tarihli ve 419 nolu toplantısinda 419 sira sayll kararl ile izin alınmıstır. Aksi bir durumun tespiti halinde AKAD Dergisinin hiçbir sorumluluğu olmayıp, tüm sorumluluk çalışmanın yazarına aittir.

Ethics Statement: Permission for this study was obtained from the Ethics Committee of Cankiri Karatekin University with the decision number 419 at the meeting dated 01/03/2021 and numbered 419. of the relevant board. In case of detection of a contrary situation, AKAD Journal has no responsibility and all responsibility belongs to the author of the study. 


\section{KAYNAKÇA}

Abratt, R., \& Goodey, S. D. (1990). Unplanned buying and in-store stimuli in supermarkets. Managerial and Decision Economics, 11(2), 111-121, https://doi.org/10.1002/mde.4090110204

Arslan, M. (2004). Măgazacıllkta atmosfer. Derin Yayınları.

Baker, J., Grewal, D., \& Parasuraman, A. (1994). The influence of store environment on quality inferences and store image. Journal of the Academy of Marketing Science, 22, 328-339, https://doi.org/10.1177/0092070394224002

Baker, J., Parasuraman, A. P., Grewal, D., \& Voss, G. B. (2002). The influence of multiple store environment cues on perceived merchandise value and patronage intentions. Journal of Marketing, 66, 120-141, https://doi.org/10.1509/jmkg.66.2.120.18470

Beatty, S. E., \& Ferrel, M. E. (1998). Impulse buying: Modeling its precursors. Journal of Retailing, 74(2), 169-191, https://doi.org/10.1016/S0022-4359(99)80092-X

Berry, D. (1990). Marketing mix for the '90s adds and S and 2Cs to 4Ps. Marketing News, 24(6), 10.

Bitner, M. J. (1992). Servicescapes: The impact of physical surroundings on customers and employees. Journal of Marketing, 56, 57-71, https://doi.org/10.1177/002224299205600205

Boomsma, A., \& Hoogland, J. J. (2001). The robustness of LISREL modeling revisited. In R. Cudeck, S. Du Toit, \& D. Sörbom (Eds.), Structural equation models: Present and future. A Festschrift in Honor of Karl Jöreskog (pp. 139-168), Scientific Software International.

Cobb, C. J., \& Hoyer W. D. (1986). Planned versus impulse purchase behavior. Journal of Retailing, 62(4), 384-409, https://psycnet.apa.org/record/1988-12512-001.

Corstjens, J., Corstjens, M., \& Lal, R. (1995). Retail competition in the fast-moving consumer goods industry: The case of France and the UK. European Management Journal, 13(4), 363-373, https://doi.org/10.1016/0263-2373(95)00028-J

Degeratu, A., Rangaswamy, A., \& Wu, J. (2000). Consumer choice behavior in online and traditional supermarkets: The effects of brand name, price, and other search attributes. International Journal of Research in Marketing, 17(1), 55-78, https://doi.org/10.1016/S0167-8116(00)00005$\underline{7}$

Dube, L., Chebat, J. C., \& Morin, S. (1995). The effects of background music on consumers' desire to affiliate in buyer-seller interactions. Psychology \& Marketing, 12(4), 305-319, https://doi.org/10.1002/mar.4220120407

Feick, L., \& Price, L. L. (1987). The market maven: A diffuser of marketplace information. Journal of Marketing, 51(1), 83-97, https://doi.org/10.2307/1251146

Ferreira, A. G., \& Coelho, F. J. (2015). Product involvement, price perceptions, and brand loyalty. Journal of Product \& Brand Management, 24(4), 349-364, https://doi.org/10.1108/JPBM-06$\underline{2014-0623}$

Hair, J. F., Anderson, R. E., Tahtam, R. L., \& Black, W. C. (1998). Multivariate data analysis. Prentice Hall International Inc.

Hausman, A. (2000). A multi-method investigation of consumer motivations in impulse buying behavior. Journal of Consumer Marketing, 17(15), 403-419, https://doi.org/10.1108/07363760010341045

Hayes, A. F. (2018). Introduction to mediation, moderation, and conditional process analysis (2nd Edition). The Guilford Press.

Hoogland, J., \& Boomsma, A. (1998). Robustness studies in covariance structure modeling-an overview and a meta-analysis. Journal of Sociological Methods \& Research, 29(3), 329-367, https://doi.org/10.1177/0049124198026003003 
Ivy, J. (2008). A new higher education marketing mix: The 7Ps for MBA marketing. International $\begin{array}{llll}\text { Journal of } & \text { Educational 2288-299, }\end{array}$ https://doi.org/10.1108/09513540810875635

Jin, B., \& Sternquist, B. (2003). The influence of retail environment on price perceptions: An exploratory study of US and Korean students. International Marketing Review, 20(6), 643-660, https://doi.org/10.1108/02651330310505231

Kaltcheva, V. D., \& Weitz, B. A. (2006). When should a retailer create an exciting store environment? Journal of Marketing, 70, 107-118, https://doi.org/10.1509/jmkg.70.1.107.qxd

Kaş, İ., \& Bozbay, Z. (2017). Mağaza atmosferi algıları itibariyle oluşan tüketici gruplarının anlık satın alma davranışlarındaki farklılıkların belirlenmesi. Kırklareli Üniversitesi Iktisadi ve İdari Bilimler Fakültesi Dergisi, 6(3), 97-110, https://dergipark.org.tr/tr/download/article-file/365515.

Kaur, P., \& Singh, R. (2007). Uncovering retail shopping motives of Indian youth. Young Consumers, 8(2), 128-138, https://doi.org/10.1108/17473610710757491

Khare, A., Achtani, D., \& Khattar, M. (2014). Influence of price perception and shopping motives on Indian consumers'attitude towards retailer promotions in malls. Asia Pacific Journal of Marketing and Logistics, 26(2), 272-295, https://doi.org/10.1108/APJML-09-2013-0097

Kim, J. (2003). College students apparel impulse buying behaviors in relation to visual merchandising [Master's Thesis, University of Georgia]. https://getd.libs.uga.edu/pdfs/kim_jiyeon_200308_ms.pdf

Kim, J. H., Kim, M., \& Lennon, S. J. (2009). Effects of web site atmospherics on consumer responses: Music and product presentation. Direct Marketing: An International Journal, 3(1), 4-19, https://doi.org/10.1108/17505930910945705

Kim, K. H. (2009). The relation among fit indexes, power, and sample size in structural equation modeling. Structural Equation Modeling: A MultidisciplinaryJournal, 12(3), 368-390, https://doi.org/10.1207/s15328007sem1203_2

Kotler, P. (1973). Atmospheric as a marketing tool. Journal of Retailing, 49(4), 48-64, http://belzludovic.free.fr/nolwenn/Kotler\%20-

\%20Atmospherics\%20as\%20a\%20marketing\%20tool\%20\%20\%28cit\%C3\%A9\%20171\%29\% 20-\%201973.pdf

Kumar, A., \& Kim, Y. K. (2014). The store-as-a-brand strategy: The effect of store environment on customer responses. Journal of Retailing and Consumer Services, 21(5), 685-695. https://doi.org/10.1016/j.jretconser.2014.04.008

Kurt, S. (2015). Pazarlama ilkeleri fiyat stratejileri. http://kisi.deu.edu.tr/sumeyra.kurt/Pazarlamaya\%20Giris/8SEKIZINCI\%20HAFTA_FIYAT.pd f.

Kurtuluş, K. (2006). Pazarlama araştırmaları (8. Baskı). Literatür Yayıncılık.

Licata, J. W., Biswas, A., \& Krishnan, B. C. (1998). Ambiguity and exaggeration in price promotion: Perceptions of the elder and nonelder consumer. Journal of Consumer Affairs, 32(1), 56-81, https://doi.org/10.1111/j.1745-6606.1998.tb00400.x

Lichtenstein, D. R., Netemeyer, R. G., \& Burton, S. (1995). Assessing the domain specificity of deal proneness: A field study. Journal of Consumer Research, 22(3), 314-326, https://doi.org/10.1086/209453

Lichtenstein, D. R., Ridgway, N. M., \& Netemeyer, R. G. (1993). Price perceptions and consumer shopping behavior: A field study. Journal of Marketing Research, 30(2), 234-245, https://doi.org/10.2307/3172830 
Liu, Y., Hongxiu, L., \& Hu, F. (2013). Websites attributes in urging online 1mpulse purchase: An empirical investigation on consumer perceptions. Decision Support Systems, 55(3), https://doi.org/10.1016/j.dss.2013.04.001

Machleit, K. A., \& Eroğlu, S. A. (2000). Describing and measuring emotional response to shopping experience. Journal of Business Research, 49(2), 101-111, https://doi.org/10.1016/S0148$\underline{\text { 2963(99)00007-7 }}$

Mattila, A. S., \& Wirtz J. (2001). Congruency of scent and music as a driver of in-store evaluations and behavior. Journal of Retailing, 77(2), 273-289, https://doi.org/10.1016/S00224359(01)00042-2

Mattila, A. S., \& Wirtz J. (2008). The role of store environmental stimulation and social factors on impulse purchasing. Journal of Services Marketing, 22(7), 562-567, https://doi.org/10.1108/08876040810909686

Mehrabian, A., \& Russell, J. A. (1974). An approach to environmental psychology. MIT Press, https://mitpress.mit.edu/books/approach-environmental-psychology

Mishra, R., \& Shukla, A. (2013). The effects of brand consciousness, sale proneness and buying urge on impulsive buying behaviour: An empirical research. International Journal of Sales \& Marketing Management Research and Development, 3(5), 1-10, http://www.tjprc.org/publishpapers/2-33-13839003001.\%20The\%20effects\%20of\%20brand.full.pdf

Monroe, K. B., \& Chapman, J. D. (1987). Framing effects on buyers'subjective product evaluations. The Association for Consumer Research, 14, 193-197, https://acrwebsite.org/volumes/6684/volumes/v14/NA-14

Moore, M., Kennedy K. M., \& Fairhurst, A. (2003). Cross-cultural equivalence of price perceptions between US and Polish consumers. International Journal of Retail \& Distribution Management, 31(5), 268-279, https://doi.org/10.1108/09590550310472433

Özgüven, N. T. (2015). Market alışverişlerinde plansız satın alma davranışında demografik farklılığı belirlemeye yönelik bir araştırma. Selçuk Üniversitesi Sosyal Bilimler Enstitüsü Dergisi, 34, 8794, http://dergisosyalbil.selcuk.edu.tr/susbed/article/view/1109/1034

Pantano, E. (2014). Innovation drivers in retail industry. International Journal of Information Management, 34(3), 344-350, https://doi.org/10.1016/j.ijinfomgt.2014.03.002

Parboteeah, D.V., Valacich, J. S., \& Wells, J. D. (2009). The influence of website characteristics on a consumer's urge to buy impulsively. Information Systems Research, 20(1), 60-78, https://doi.org/10.1287/isre.1070.0157

Park, E. J., Kim, E. Y., \& Forney, J. C. (2006). A structural model of fashion-oriented impulse buying behavior. Journal of Fashion Marketing and Management, 10(4), 433-446, https://doi.org/10.1108/13612020610701965

Pentecost, D. R., \& Andrews, L. (2010). Fashion retailing and the bottom line: The effects of generation cohorts, gender, fashion fanship, attitudes and impulse buying on fashion expenditure. Journal of Retailing and Consumer Services, 17(1), 43-52, https://doi.org/10.1016/j.jretconser.2009.09.003

Piron, F. (1991). Defining impulse purchasing. Advances in Consumer Research, 18, 509-514, https://www.acrwebsite.org/volumes/7206/volumes/v18/NA-18

Prasad, J. S., \& Aryasri, A. R. (2009). Determinants of shopper behaviour in e-tailing: An empirical analysis. Paradigm, 13(1), 73-83, https://doi.org/10.1177/0971890720090110

Rehman, F., Ilyas, M., Nawaz, T., \& Hyder, S. (2014). How facebook advertising affects buying behavior of young consumers: The moderating role of gender. Academic Research International, 
https://www.researchgate.net/publication/324839226_How_Facebook_Advertising_Affects_ Buying_Behavior_of_Young_Consumers_The_Moderating_Role_of_Gender.

Rook, D. W. (1987). The buying impulse. Journal of Consumer Research, 14(2), 189-199, https://doi.org/10.1086/209105

Rook, D. W., \& Fisher, R. J. (1995). Normative influences on impulsive buying behavior. Journal of Consumer Research, 22(3), 305-313, https://doi.org/10.1086/209452

Saad, M., \& Metawie, M. (2015). Store environment, personality factors and impulse buying behavior in Egypt: The mediating roles of shop enjoyment and 1mpulse buying tendencies. Journal of Business and Management Sciences, 3(2), 69-77, https://doi.org/10.12691/jbms-3-2-3

Schermelleh-Engel, K., Moosbrugger, H., \& Müller, H. (2003). Evaluating the fit of structural equation models: Tests of significance and descriptive goodness-of-fit-measures. Methods of Psychological Research Online, 8(2), 23-74, https://www.researchgate.net/publication/251060246 Evaluating the Fit of Structural Equati on Models Tests of Significance and Descriptive Goodness-of-Fit Measures

Sharma, B. K., Mishra, S., \& Arora, L. (2018). Does social medium influence impulse buying of Indian buyers. Journal of Management and Research, 18(1), 27-36, https://www.researchgate.net/publication/324684804_Does_Social_Medium_Influence_Impuls e_Buying_of_Indian_Buyers\#fullTextFileContent

Solomon, M. R., Dahl, D. W., White, K., Zaichkowsky, J. L., \& Polegato, R. (2014). Consumer behavior: Buying, having, and being. Pearson.

Spangenberg, E. R., Grohmann, B., \& Sprott, D. E. (2005). It's beginning to smell (and sound) a lot like Christmas: The interactive effects of ambient scent and music in a retail setting. Journal of Business Research, 58(11), 1583-1589. https://doi.org/10.1016/j.jbusres.2004.09.005

Spies, K., Hesse, F., \& Loesch, K. (1997). Store atmosphere, mood and purchasing behavior. International Journal of Research in Marketing, 14, 1-17, https://www.academia.edu/15977913/Store_atmosphere_mood_and_purchasing_behavior

Stern, H. (1962). The significance of impulse buying today. Journal of Marketing, 26(2), 59-62, https://doi.org/10.2307/1248439

Topuz, Y. V., \& Çambaş1, İ. (2014). Asgari ücretli tüketicilerin fiyat ve fiyat kalite algısı: Cep telefonu ürünleri üzerine bir araştırma. Niğde Üniversitesi İBF Dergisi, 7(1), 315-327, https://dergipark.org.tr/tr/download/article-file/185108

Triwidisari, A., Nurkhin, A., \& Muhsin, M. (2017). The relationships between instagram social media usage, hedonic shopping motives and financial literacy on impulse buying. Dinamika Pendidikan, 12(2), 170-181, https://doi.org/10.15294/dp.v12i2.13565

Turley, L. W., \& Milliman, R. E. (2000). Atmospheric effects on shopping behavior: A review of the experimental evidence. Journal of Business Research, 49(2), 193-211, https://doi.org/10.1016/S0148-2963(99)00010-7

Wakefield, K. L., \& Baker, J. (1998). Excitement at the mall: Determinants and effects on shopping response. Journal of Retailing, 74(4), 515-539, https://doi.org/10.1016/S0022-4359(99)80106-7

Wathcravesringkan, K. T., Yan, R., \& Yurchisin, J. (2008). Cross-cultural invariance of consumers'price perception measures: Eastern Asian. International Journal of Retail \& Distribution Management, 36(10), 759-779, https://doi.org/10.1108/09590550810900982

Yu, S. F. (2008). Price perception of online airline ticket shoppers. Journal of Air Transport Management, 14(2), 66-69, https://doi.org/10.1016/j.jairtraman.2007.11.002

Zhou, L., \& Wong, A. (2004). Consumer impulse buying and 1n-store stimuli in Chinese supermarkets. Journal of International Consumer Marketing, 16(2), 37-53, https://doi.org/10.1300/J046v16n02_03 